\title{
PENGARUH PENGELUARAN PEMERINTAH SEKTOR PENDIDIKAN, KESEHATAN, DAN INFRASTUKTUR TERHADAP PERTUMBUHAN EKONOMI DAN PENINGKATAN PEMBANGUNAN MANUSIA DI PROVINSI KALIMANTAN TIMUR
}

\author{
Heri Suparno \\ Fakultas Ekonomi Universitas Mulawarman \\ E-mail: herisuparno212@gmail.com
}

\begin{abstract}
The purpose of this research were: 1) determining the direct effect of government spending on education, health and infrastructure to economic growth and human development index, 2) investigating the direct impact of economic growth on the human development index, 3) describing the indirect consequence of government spending on the sector education, health and infrastructure to the human development index through economic growth. In order to examine the hypothesis testing, the researcher employed path analysis and used the data derived from government spending files which comprised the expenditures on education, health and infrastructure, human development index and economic growth from 1997 up to 2011. The analysis showed that there is a direct effect of government spending on education, health and infrastructure to the human development index and economic growth and indirect influences of the government expenditure on education, health and infrastructure to the human development index through economic growth.
\end{abstract}

Keywords: Government Spending on Education, Health, Infrastructure, Human Development Index, Economic Growth

\begin{abstract}
Abstrak
Tujuan dari penelitian ini adalah: 1) menganalisis pengaruh pengeluaran pemerintah sektor pendidikan, kesehatan dan infrastuktur berpengaruh langsung terhadap pertumbuhan ekonomi dan indeks pembangunan manusia, 2) menganalisis pengaruh pertumbuhan ekonomi berpengaruh langsung terhadap indeks pembangunan manusia, 3) menganalisis pengaruh pengeluaran pemerintah sektor pendidikan, kesehatan dan infrastuktur berpengaruh tidak langsung terhadap indeks pembangunan manusia melalui pertumbuhan ekonomi. Dalam rangka menguji analisis hipotesis penulis menggunakan alat analisis Jalur. Data yang digunakan dalam penelitian ini adalah pengeluaran pemerintah sektor pendidikan, kesehatan dan infrastuktur, indeks pembangunan manusia dan pertumbuhan ekonomi pada tahun 1997 sampai dengan 2011. Hasil analisis menunjukkan bahwa terdapat pengaruh langsung antara pengeluaran pemerintah sektor pendidikan, kesehatan dan infrastuktur terhadap indeks pembangunan manusia dan pertumbuhan ekonomi. Terdapat pengaruh tidak langsung antara pengeluaran pemerintah sektor pendidikan, kesehatan dan infrastuktur terhadap indeks pembangunan manusia melalui pertumbuhan ekonomi.
\end{abstract}

Kata Kunci: Pengeluaran Pemerintah Sektor Pendidikan, Kesehatan, Infrastuktur, Indeks Pembangunan Manusia dan Pertumbuhan Ekonomi. 
Pembangunan merupakan suatu proses multidimensional yang melibatkan perubahanperubahan besar dalam struktur sosial, sikap mental yang sudah terbiasa dan lembagalembaga nasional termasuk pula percepatan (akselerasi) pertumbuhan ekonomi, pengurangan ketimpangan dan pemberantasan kemiskinan yang absolut. Pembangunan ekonomi merupakan suatu proses yang menyebabkan pendapatan per kapita suatu masyarakat meningkat dalam jangka panjang.

Indikator keberhasilan pembangunan suatu daerahbisa dilihat laju pertumbuhanekonominya. Pertumbuhan ekonomi yang tinggi dan berkelanjutan merupakan kondisi utama bagi kelangsungan pembangunan ekonomi. Karena penduduk bertambah terus, maka dibutuhkan penambahan pendapatan setiap tahunnya. Hal ini dapat terpenuhi lewat peningkatan output secara agregat baik barang maupun jasa atau Produk Domestik Bruto (PDB) setiap tahunnya. Jadi, menurut ekonomi makro, pengertian pertumbuhan ekonomi merupakan penambahan PDB yang berarti juga penambahan pendapatan nasional.

Tingkat pertumbuhan ekonomi yang tinggi hanya sedikit manfaatnya dalam memecahkan masalah kemiskinan, masih banyak penduduk yang memiliki pendapatan di bawah standar kebutuhan hidupnya. Pertumbuhan ekonomigagal untuk mengurangi bahkan menghilangkan besarnya kemiskinan absolut. Jadi pertumbuhan PDB yang cepat tidak secara otomatis meningkatkan taraf hidup masyarakatnya, dengan kata lain bahwa apa yang disebut dengan "Trickle Down Effects" atau efek cucuranke bawah darimanfaat pertumbuhan ekonomi bagi penduduk miskin tidak terjadi seperti apa yang diharapkan bahkan berjalan cenderung sangat lambat. Selama proses awal pembangunan terjadi suatu dilema yaitu antara pertumbuhan ekonomi yang tinggidengan distribusipen- dapatan, ini menjadimasalah yang telah lama dan harus dihadapi oleh negara-negara miskin dan berkembang. Trade off atau pertukaran antara pertumbuhan ekonomi dengan distribusi pendapatan di masing-masing daerah selalu terjadi.

Professor Kuznet telah mengemukakan bahwa pada tahap-tahap awal pertumbuhan ekonomi, distribusi pendapatan cenderung memburuk, dengan katalain ketimpangan yang tinggi. Namun, pada tahap-tahap berikutnya hal tersebut akan membaik. Hipotesis ini dikenal dengan hipotesis “U-Terbalik” Kuznet. Sesuai dengan rangkaian perubahan kecenderungan distribusi pendapatan dengan ukuran koefisien Gini dan pertumbuhan PDB perkapita yang akan terlihat seperti kurva yang berbentuk huruf U terbalik. Menurut Kuznet distribusi pendapatan akan meningkat sejalan dengan pertumbuhan ekonomi.

Kalimantan Timur sebagai salah satu provinsi di Indonesia juga tidak terlepas dari masalah ketimpangan distribusi pendapatan seperti apa yang telah dialami daerah lainnya. Provinsi Kalimantan Timur tentu saja memiliki berbagai persoalan yang harus diselesaikan, di antaranya adalah masalah pertumbuhan ekonomi dan kesenjangan distribusi pendapatan. Aspek pemerataan pendapatan merupakan hal yang penting untuk dipantau, karena pemerataan hasil pembangunan merupakan salah satu strategi dan tujuan pembangunan nasional di Indonesia.

Produk Domestik Regional Bruto (PDRB) Kalimantan Timur memberikan gambaran kinerja pembangunan ekonomi dari waktu ke waktu, sehingga arah perekonomian daerah akan lebih jelas. Produk Domestik regional Bruto (PDRB) atas dasar harga konstan digunakanuntuk menunjukan laju pertumbuhan ekonomi secara keseluruhan dari tahun ke tahun. 
Menurut Samuelson dan Nordhaus (2005) ada empat faktor sebagai sumber pertumbuhan ekonomi. Faktor-faktor tersebut adalah (1) sumber daya manusia, (2) sumber daya alam, (3) pembentukan modal, dan (4) teknologi. Pengeluaran pemerintah berperan dalam pembentukan modal melalui pengeluaran pemerintah diberbagai bidang seperti sarana dan prasarana. Pembentukan modal di bidang sarana dan prasarana ini umumnya menjadi social overhead capital (SOC) yang sangat penting dalam pertumbuhan ekonomi. SOC ini sangat penting karenapihak swasta tidak akan mau menyediakan berbagai fasilitas publik, namun tanpa adanya fasilitas publik ini maka pihak swasta tidak berminat untuk menanamkan modalnya.

Pertumbuhan ekonomi dan peningkatan pendapatan akan terdorong naik dengan adanya berbagai fasilitas publik. Pengeluaran pemerintah yang terdapat dalam Anggaran Pendapatan Belanja Negara (APBN) merupakan salah satu alat kebijakan fiskal pemerintah. Pemerintah dapat menggunakannya untuk mengelola perekonomian negara. APBN pada perkembangannya telah mengalami banyak perubahan struktur. Pengeluaran pemerintah atas pendidikan, kesehatan dan infrastruktur pada dasarnya merupakan suatu investasi terhadap pertumbuhan ekonomi. Efek pembangunan pada ketiga sektor tersebut tidak dapat berdampak langsung melainkan membutuhkan beberapa periode untuk dapat merasakan dampaknya. Terdapat time lag ketika pemerintah mengeluarkan anggaran pembangunan atau belanja Negara untuk ketiga sektor tersebut dengan dampak kebijakan tersebut, maka dibutuhkan suatu penelitian yang menggunakan runtut waktu (time series) cukup panjang.

Fungsi pemerintah menurut Dumairy (1999) adalah alokatif, distributif, stabilitif, dan dinamisatif pemerintah harus dapat menciptakan kesejahteraan bagi masyarakat. Pemerintah akan melakukan pengeluaran belanja pembangunan sebagai langkah untuk menjalankan fungsi-fungsinya tersebut. Belanja pembangunan merupakan pengeluaran pemerintah untuk memenuhi kebutuhan pembangunan. Tujuan daripembangunan salah satunya untuk meningkatkan kesejahteraan masyarakat. Kesejahteraan masyarakat dapat diwujudkan dengan pemenuhan kebutuhan dasar seperti kesehatan, pendidikan dan infrastruktur. Pemenuhan kebutuhan dasar akan meningkatkan kualitas sumber daya manusia. Sumber daya yang berkualitas akan mampu memberikan kontribusi dalam kemajuan teknologi yang lebih mutakhir sehingga dapat meningkatkan efisiensi produksi.

Menurut Mankiw (2008) pengembangan sumber daya manusia dapat dilakukan dengan perbaikan kualitas modal manusia. Modal manusia dapat mengacu pada pendidikan, namun juga dapat digunakan untuk menjelaskan jenis investasi manusia lainnya yaitu investasi yang mendorong ke arah populasi yang sehat yaitu kesehatan. Pendidikan dan kesehatan merupakan tujuan pembangunan yang mendasar di suatu wilayah. Kesehatan merupakan inti dari kesejahteraan, dan pendidikan adalah hal yang pokok untuk mencapai kehidupan yang layak. Pendidikan memiliki peran yang penting dalam membentuk kemampuan sebuah negara berkembang untuk menyerap teknologi modern dan untuk mengembangkan kapasitas agar tercipta pertumbuhan serta pembangunan yang berkelanjutan (Todaro, 2006).

Perbaikan kualitas modal manusia tergantung pada tersedianya infrastruktur untuk menunjang investasi pada sumber daya manusia. Menurut Friawan (2008) ada tiga alasan utama mengapa infrastruktur penting da- 
lam sebuah integrasiekonomi. Alasan pertama adalah ketersedian infrastruktur yang baru merupakan mesinutama pembangunan ekonomi. Kedua, untukmemperoleh manfaat yang penuh dari integrasi, ketersediaan jaringan infrastruktur sangat penting dalam memperlancar aktivitas perdagangan dan investasi. Alasan ketiga adalah perhatian terhadap perbaikan infrastruktur juga penting untuk mengatasi kesenjangan pembangunan ekonomi antar negara. Infrastruktur terdiri dari beberapa subsektor, infrastruktur dalam bentuk perumahan dan transportasi merupakan cukup penting untuk menunjang kehidupan masyarakat.

Selama tahun 1969 hingga 2009 proporsi pengeluaran pemerintah atas pendidikan, kesehatan, perumahan dan transportasi berubah-ubah. Jumlah proporsi pengeluaran pemerintah terbanyak terdapat pada sektor transportasi dan terendah pada sektor kesehatan. Proporsi pengeluaran pemerintah atas pendidikan berkisar antara 3-4 persen sejak tahun 1969 hingga 1999 kecuali pada tahun 1979 dan 1984. Pada tahun 2004 proporsi pengeluaran pemerintah atas pendidikan mulai meningkat seiring dengan ketentuan Undang-undang yang mensyaratkan pengeluaran pemerintah minimal sebesar 10 persen dariAPBN. Proporsi pengeluaran pemerintah atas kesehatan hanya sebesar satu hingga dua persen saja, demikian pula dengan pengeluaran pemerintah atas perumahan.

Pengeluaran pemerintah atas pendidikan, kesehatan dan infrastruktur pada dasarnya merupakan suatu investasi terhadap pertumbuhan ekonomi. Efek pembangunan pada ketiga sektor tersebut tidak dapat berdampak langsung melainkan membutuhkan beberapa periode untuk dapat merasakan dampaknya. Terdapat time lag ketika pemerintah mengeluarkan anggaran pembangunan atau belanja Negara untuk ketiga sektor terse- but dengan dampak kebijakan tersebut, maka dibutuhkan suatu penelitian yang menggunakan runtut waktu (time series) cukup panjang.

Penelitian dengan menggunakan runtun waktu akan membantu melihat pengaruh pengeluaran pemerintah pada ketiga sektor tersebut terhadap pertumbuhan ekonomi. Investasi pemerintah dalam pendidikan, kesehatan dan infrastruktur akan menyebabkan peningkatan kualitas modal manusia dan prasarana fisik, hal ini juga akan memacu investasi ekonomi. Investasi ekonomi selanjutnya akan mempengaruhi pertumbuhan ekonomi, karena banyaknya modal yang tersedia untuk pembangunan.

Perubahan paradigma pembangunan pada dasarnya adalah menjadikan manusia sebagai tujuan akhir pembangunan, bukan sebagai alat pembangunan. Pembangunan manusia menekankan terpenuhinya kehidupan yang layak bagi manusia. Pertumbuhan ekonomi dapat menunjang pemenuhan hak dan kebebasan, serta mempromosikan simbiosis antara pembangunan ekonomi dan keadilan sosial; antara ekonomi yang maju dan politik yang sehat; serta antara kesejahteraan masyarakat dan individu.

Pembangunan yang menjamin keberlanjutan hidup manusia dan berkeadilan sosial, merupakan kewajiban negara untuk memenuhi kewajibannya terhadap hak atas pembangunan bagi seluruh rakyat. Oleh karena itu, program pembangunan harus diarahkan untuk pemerataan dan pengurangan pemiskinan melalui komitmen visi pembangunan nasional, dan diimplementasikan melalui konsep pembangunan yang berpihak kepada orang miskin (pro-poor development) serta berbasis pada keadilan gender (being based on justice of gender). Keberadaan pembangunan manusia sebagai indikator kesejahteraan dan sosial masyarakat, sangat penting 
bagi bangsa Indonesia karena: (1) Pembangunan pada hakekatnya merupakan pembangunan manusia, (2) Pembangunan manusia Indonesia masih sangat tertinggal bila dibandingkan dengan negara-negara lain, dan (3) Pengeluaran pemerintah untuk pendidikan dan kesehatan, yang notabene berpengaruh pada kualitas SDM, masih sangat rendah.

Teori pertumbuhan ekonomi yang berkembang saat ini didasari kepada kapasitas produksitenaga manusia didalamproses pembangunan atau disebut juga investment in human capital. Hal ini berartipeningkatan kemampuan masyarakat menjadi suatu tumpuan yang paling efisien dalam melakukan pembangunan di suatu wilayah.

Asumsi yang digunakan dalam teori human capital adalah bahwa pendidikan formal merupakan faktor yang dominan untuk menghasilkan masyarakat berproduktivitas tinggi. Teori human capital dapat diaplikasikan dengan syarat adanya sumber teknologitinggi secara efisien dan adanya sumber daya manusia yang dapat memanfaatkan teknologi yang ada. Teori ini percaya bahwa investasi dalam hal pendidikan sebagai investasi dalam meningkatkan produktivitas masyarakat.

Investasi dalam hal pendidikan mutlak dibutuhkan maka pemerintah harus dapat membangun suatu sarana dan sistem pendidikan yang baik. Alokasi anggaran pengeluaran pemerintah terhadappendidikan merupakan wujud nyata dari investasi untuk meningkatkan produktivitas. Pengeluaranpembangunan pada sektor pembangunan dapat dialokasikan untuk penyediaan infrastruktur pendidikan dan menyelenggarakan pelayanan pendidikan kepada seluruh penduduk Indonesia secara merata. Anggaran pendidikan sebesar 20 persen merupakan wujud realisasi pemerintah untuk meningkatkan pendidikan.

Menurut E.Setiawan (2006) implikasi dari pembangunan dalam pendidikan adalah kehidupan manusia akan semakin berkualitas. Dalam kaitannya dengan perekonomian secara umum (nasional) semakin tinggi kualitas hidup suatu bangsa, semakin tinggi tingkat pertumbuhan dan kesejahteraan bangsa tersebut. Semakin tinggi kualitas hidup / investasi sumber daya manusia yang kualitas tinggi akan berimplikasi juga terhadap tingkat pertumbuhan ekonomi nasional.

Kesehatan merupakan kebutuhan mendasar bagi setiap manusia, tanpa kesehatan masyarakat tidak dapat menghasilkan suatu produktivitas bagi negara. Kegiatan ekonomi suatu negara akan berjalan jika ada jaminan kesehatan bagi setiap penduduknya. Terkait dengan teori human capital bahwa modalmanusia berperan signifikan, bahkan lebih penting daripada faktor teknologi dalam memacu pertumbuhan ekonomi(E.Setiawan, 2006).

Negara sedang berkembang sepertiIndonesia sedang mengalami tahap perkembangan menengah, di mana pemerintah harus menyediakan lebih banyak sarana publik seperti kesehatan untuk meningkatkan produktifitas ekonomi. Sarana kesehatan dan jaminan kesehatan harus dirancang sedemikian rupa oleh pemerintah melalui pengeluaran pemeritah. Menurut penelitian yang dilakukan Tri Haryanto (2005) menunjukkan bahwa sektor kesehatan, tingkat persalinan yang ditolong tenaga medis dan persentase pengeluaran pemerintah untuk kesehatan berpengaruh secara signifikan terhadap tingkat kematian balita. Secara umum, kesehatan menunjukkan bahwa peningkatan pengeluaran pemerintah untuk sektor kesehatan terbukti cukup besar terhadap peningkatan kinerja sektor tersebut.

Mengingat besarnya pengaruh pengeluaran pemerintah terhadap peningkatan kinerja dari kesehatan maka perlu adanya upaya secara bertahap dari pemerintah untuk meningkatkan pengeluarannya pada sektor 
kesehatan. Masih rendahnya kapasitas anggaran daerah untukmeningkatkan alokasi anggaran dalam sektor kesehatan menimbulkan implikasi masih harus dominannya pemerintah pusat sebagai sumber pembiayaan.

Infrastruktur tidak kalah pentingnya dengan pendidikan dan kesehatan, infrastruktur merupakan suatu sarana (fisik) pendukung agar pembangunan ekonomi suatu negara dapat terwujud. Infrastruktur terdiri dari beberapa subsektor, beberapa di antaranya yang cukup dominandalampembangunan ekonomi adalah perumahan dan transportasi. Infrastruktur juga menunjukkan seberapa besar pemerataan pembangunan terjadi. Suatu negara dengan pertumbuhan ekonomi tinggi akan mampu melakukan pemerataan pembangunan kemudian melakukan pembangunan infrastruktur ke seluruh bagian wilayahnya.

Perekonomian yang terintegrasi membutuhkan pembangunan infrastruktur. Menurut kajian ilmiah yang dilakukan Deni Friawan (2008) menjelaskan setidaknya ada tiga alasan utama mengapa infrastruktur penting dalam sebuah integrasi ekonomi. Pertama, ketersedian infrastruktur yang baik merupakan mesin utama pemacu pertumbuhan ekonomi, misalnya studi The World Bank (2004) menyatakan bahwa tingkat pertumbuhan ekonomi yang rendah dalam beberapa tahun terakhir pasca krisis ekonomi 1998 salah satunya dipengaruhi rendahnya tingkat investasi.

Kurangnya ketersediaan infrastruktur merupakan salah satu hambatan utama dalam perbaikan iklim investasi di Indonesia. Kedua, untuk memperoleh manfaat yang penuh dari integrasi, ketersediaan jaringan infrastruktur sangat penting dalam memperlancar aktifitas perdagangan dan investasi. Penurunan tarif akibat integrasi ekonomi tidak dapat menjamin bahwa akan meningkatkan aktivitas perdagangan dan investasi tanpa adanya dukungan dariinfrastruktur yang memadai. Ketiga, perhatian terhadap perbaikan infrastruktur juga penting untuk mengatasi kesenjangan pembangunan ekonomi antar negara-negara di Asia dan juga mempercepat integrasi perekonomian Asia.

Permasalahan infrastruktur di Indonesia diakibatkan oleh masalah sektoral dan lintas sektoral. Maka dibutuhkan kebijakankebijakan yang dapat menjembatani sektorsektor terkait. Seperti dari sisi pembiayaan pemerintah diharapkan mampu membuat mekanisme penentuan resiko investasi dan mengembangkan metodologi yang dapat secara mudah diterapkan. Di saat bersamaan, mengingat mobilisasi investasi dari sektor swasta membutuhkan waktu, pemerintah diharapkan tetap memberikan perhatian pada peningkatan investasi publik sehingga kebutuhan infrastruktur dapat terpenuhi, salah satunya melalui peningkatan pengeluaran pemerintah atas infrastruktur.

Namun jika pengeluaran pemerintah saja tidak cukup diperlukan peran pihak swasta. Peran pemerintah untuk meningkatkan perhatian pihak swasta adalah dengan bantuan pembebasan lahan, subsidi operasional dan modal, dan jaminan resiko usaha. Peningkatan pengeluaran pemerintah atas infrastruktur juga harus diikuti dengan efektifitas dan efisiensi dari pengeluaran tersebut. Hal tersebut dilakukan untuk meningkatkan kualitas infrastruktur yang dibangun dan agar terciptanya transparansi dalam proses pengadaan barang dan pembangunan.

Teori pertumbuhan baru menekankan pentingnya peranan pemerintah terutama dalam meningkatkan pembangunan modal manusia (human capital) dan mendorong penelitian dan pengembangan untuk meningkatkan produktivitas manusia. Kenyataannya 
dapat dilihat dengan melakukan investasipendidikan akan mampu meningkatkan kualitas sumber daya manusia yang diperlihatkan dengan meningkatnya pengetahuan dan keterampilan seseorang. Semakin tinggi tingkat pendidikan seseorang, maka pengetahuan dan keahlian juga akan meningkat sehingga akan mendorong peningkatan produktivitas kerjanya. Perusahaan akan memperoleh hasil yang lebih banyak dengan memperkerjakan tenaga kerja dengan produktivitas yang tinggi, sehingga perusahaan juga akan bersedia memberikan gaji yang lebih tinggi bagi yang bersangkutan. Di sektor informal seperti pertanian, peningkatan keterampilan dan keahlian tenaga kerja akan mampu meningkatkan hasil pertanian, karena tenaga kerja yang terampil mampu bekerja lebih efisien. Pada akhirnya seseorang yang memiliki produktivitas yang tinggi akan memperoleh kesejahteraan yang lebih baik, yang diperlihatkan melalui peningkatan peningkatan pendapatan maupun konsumsinya.

Todaro (2000) juga mengatakan bahwa pembangunan manusia merupakan tujuan pembangunan itu sendiri. Yang mana pembangunan manusia memainkan peranan kunci dalam membentuk kemampuan sebuah negara dalammenyerap teknologi modern dan untuk mengembangkan kapasitasnya agar tercipta pertumbuhan serta pembangunan yang berkelanjutan.

Menurut Yani Mulyaningsih (2011) indeks pembangunan manusia memuat tiga dimensi penting dalam pembangunan yaitu terkait dengan aspek pemenuhankebutuhan akan hidup panjang umur (Longevity) dan hidup sehat (healthy life), untuk mendapatkan pengetahuan (the knowledge) dan mempunyai akses kepada sumber daya yang bisa memenuhi standar hidup.

Paradigma baru dalam pembangunan yang menjadikan manusia sebagai tujuan akhir dari pembangunan adalah kunci keberhasilan dalam mewujudkan pembangunan yang koperhensif. Pembangunan manusia mampu mengupayakan terpenuhinya kehidupan yang layak bagi manusia. Sedang pertumbuhan ekonomi dapat menunjang pemenuhan hak, kebebasan serta keadilan sosial antara kesejahteraan masyarakat dan individu. Perbaikan kualitas manusia serta mendorong pertumbuhan ekonomi yang tinggi menjadi penting untuk dikerjakan guna mewujudkan Pembangunan yang dapat menjamin keberlanjutan hidup manusia.

\section{Metode Penelitian}

Jenis penelitian ini adalah penelitian deskriptif kuantitatif. variabel yang digunakan dalam penelitian ini yaitu Indeks pembangunan Manusia (IPM), Pertumbuhan ekonomi produk domestik regional bruto (PDRB) atas dasar harga konstan tahun 1997-2011, dalam persentase $(\%)$, pengeluaran pemerintah di tiga sektor meliputi pendidikan, kesehatan dan infrastruktur tahun 1997-2011, dalampersentase (\%). Lokasi penelitian dilakukan di Provinsi Kalimantan Timur.

Dalam penelitian ini, metode analisis data yang akan digunakan adalah analisis jalur (path analysis). Metode analisis jalur digunakan untuk menganalisis pola hubungan antar variabel. Tujuan analisis jalur adalah untuk mengetahui pengaruh langsung maupun tidak langsung melaluiseperangkat variabel bebas terhadap variabel terikat. Pengaruh dalamjalur tersebut ditunjukkanolehkoefisienjalur pada setiap diagramjalur dari hubungan kausal antar variabel bebas terhadap variabel terikat (Riduwan, 2006:89).

Pengaruh variable intervening digunakan metode analisis jalur (path analysis). Analisis jalur merupakan perluasan dari analisis regresi berganda atau analisis jalur adalah penggunaan analisis regresi untuk 
menaksir hubungan kausalitas antar variabel yang telah ditetapkan sebelumnya berdasarkan teori.Analisis jalur sendiri tidak dapat menentukan hubungan sebab akibat dan juga tidak dapat digunakan sebagai subtitusi bagi peneliti untuk melihat hubungan kausalitas antar variabel. Hubungan kausalitas antar variabel telah dibentuk dengan model berdasarkan landasan teoritis, yang dilakukan oleh analisis jalur adalah menentukan pola hubungan antara tiga atau lebih variabel. Persamaan analisis jalur dalam penelitian ini adalah sebagai berikut: 1) Persamaan substuktur pertama adalah sebagai berikut: $\mathrm{Y}_{1}=$ $\mathrm{b}_{1} \mathrm{Y}_{1} \mathrm{X}_{1}+\mathrm{b}_{2} \mathrm{Y}_{1} \mathrm{X}_{2}+\mathrm{b}_{3} \mathrm{Y}_{1} \mathrm{X}_{3}+\mathrm{E}_{1}$ Sumber: (Sunyoto, 2012: 61). 2) Persamaan substuktur kedua adalah sebagai berikut: $\mathrm{Y}_{2}$ $=b_{1} Y_{2} X_{1}+b_{2} Y_{2} X_{2}+b_{3} Y_{2} X_{3}+b_{4} Y_{2} Y_{1}+$ $\mathrm{E}_{2}$ Sumber: (Sunyoto, 2012: 61) Analisis persamaan dalam substruktur penyelesaiannya dilakukan dengan bantuan ProgramSPSS for Windows Release 19.0.

Penelitian ini digunakan alat analisis uji asumsi klasik, yaitu Uji Multikolinieritas, Penyimpangan multikolinearitas artinya antar variabel independen yang terdapat dalam model memiliki hubungan yang sempurna atau mendekati sempurna (Algifari, 2000:84). Persamaan variabel inflasijika memiliki nilai yang semakin besar maka menunjukkan multikolinearitas akan lebih sederhana. Bila nilai faktor varianinflasi lebih dari 10, maka terjadimultikolinearitas (Hakim, 2001:303).

Alat analisis kedua Uji Heteroskedastisitas, Penyimpangan heteroskedastisitas menurut Algifari (2000:85) artinya varians variabel dalam model tidak sama (konstan). Pengujian heteroskedastisitas dilakukan dengan menggunakan teknik dari Park, yaitu dengan melakukan analisis regresi dengan menggunakan nilai residual sebagai variabel dependen yang diperoleh dari analisis regresi biasa. Jika semua variabel independen signifikan secara statistik, maka dalam model terdapat heteroskedastisitas (Algifari, 2000:88) atau membandingkan nilai thitung dan nilait table, bila t hitung lebih kecil dari t table maka tidak terjadi heteroskedastisitas. Untuk menguji hipotesis, maka menggunakan ujir, uji $\mathrm{R}^{2}$, ujiF dan uji t, untuk mengetahui pengaruh antara variabel bebas dengan variabel terikatnya.

Selain uji asumsi klasik multikolinieritas danheterokedastiisitas, uji asumsi klasik yang lain adalah uji normmalitas, di mana akan menguji data variabel bebas $(X)$ dan data variabel terikat $(\mathrm{Y})$ pada persamaan regresi yang dihasilkan. Berdistribusi normal atau berdistribusi tidak normal. Uji asumsi klasik normalitas, terdapat dua cara untuk mengetahuinya: 1. Cara statistik yaitu dalam menguji data variabel bebas dan data variabel terikat berdistribusi normal atau tidak pada cara statistic inimelaluinilaikemiringan kurva(skew$n e s s=\alpha 3$ ) atau keruncingan kurva (kurtosis $=\alpha 4)$ diperbandingkan dengan nilaiZtabel. 2. Cara grafik histogram dan normal probability plots yaitu cara normal probability plot lebih handal dari pada cara grafik histogram, karena cara ini membandingkan data rill dengan data distribusi normal (otomatis dari computer) secara komulatif. Suatu data dikatakan berdistribusi normal jika garis data rill mengikuti garis diagonal. (Sunyoto, 2010:108).

Persamaan regresi yang baik adalah yang tidak memiliki masalah autokorelasi, masalah autokorelasi baru timbul jika ada korelasi secara linier antara kesalahan pengganggu periode $t$ (berada) dengan dengan kesalahan penganggu periode $\mathrm{t}-1$ (sebelumnya) (Sunyoto, 2010: 110). Salah satu ukuran dalam menentukan ada tidaknya masalah autokorelasi dengan uji Durbin-Watson(DW) 
dengan ketentuan sebagai berikut: Terjadi autokorelasi positif, jika nilai DW dibawah -2 (DW <-2), Tidak terjadiautokorelasi, jika nilai DW berada di antara -2 dan +2 atau -2 $\leq \mathrm{DW} \leq+2$. Terjadi autokorelasi negatif jika nilai DW diatas +2 atau $\mathrm{DW}>+2$. ( $\mathrm{Su}-$ nyoto, 2010: 110).

Perhitungan Koefisien Korelasi (R) dan Koefisien Determinasi $\left(\mathrm{R}^{2}\right)$ juga digunakan dalam penelitian ini di mana Koefisien korelasi digunakan untuk menjawab seberapa erat, atau seberapa kuat hubungan linier antara $\mathrm{X}$ dan $\mathrm{Y}$, koefisien kolerasi yang digunakan disini adalah Pearson Correlation Coefficient, menurut Sugiyono (2005:248) perhitungan ini dinyatakan dengan rumus:

$R=\sqrt{\frac{b_{1} \sum X_{1} Y+b_{2} \sum X_{2} Y+b_{3} \sum X_{3} Y+b_{4} \sum X_{4} Y+b_{5} \sum X_{5} Y}{\sum Y_{2}}}$

Sumber: (Sugiyono, 2005:149)

Untuk dapat memberikan penafsiran terhadap koefisien korelasi yang ditemukan tersebut besar atau kecil, maka dapat pedoman pada ketentuan yang tertera pada tabel 1 .

Koefisien determinasi digunakan untuk mengetahui besarnya pengaruh antara variabel tidak bebas dengan variabel bebas. Semakin besar nilai $\mathrm{R}^{2}$, maka semakin tepat model regresi yang dipakai sebagai alat analisis, karena total variasi dapat menjelaskan variabel tidak bebas. Untuk menghitung digunakan rumus sebagai berikut (Sunyoto, 2010: 79):

$$
R^{2}=\frac{b_{1} \sum X_{1} Y+b_{2} \sum X_{2} Y}{\sum Y^{2}}
$$

Apabila koefisien determinasi $\left(\mathrm{R}^{2}\right)$ mendekati angka satu (1) berarti terdapat hubungan yang kuat (Djarwanto dan Pangestu S, 2001:324).

Pengujian serentak digunakan dalam penelitian ini untuk mengetahui apakah secara bersama-sama koefisien regresi variabel bebas mempunyai pengaruh atau tidak terhadap variabel terikatnya. Pengujian terhadap koefisien regresimenurut Sudjana (2002:355), Uji F ini digunakan rumus: Menentukan hipotesis nihil dan hipotesis alternatif $\mathrm{H}_{\mathrm{o}}: \beta=0 \quad$ : Secara signifikan variabel bebas tidak berpengaruh terhadap variabel terikat.

$\mathrm{H}_{\mathrm{a}} \beta \neq 0 \quad$ : $\quad$ Secara signifikan variabel bebas berpengaruh terhadap variabel terikat.

Tahap selanjutnya dalam melakukan uji serentak yaitu dengan melakukan Perhitungan nilai $F$ yang digambarkan dalam rumus sebagaiberikut:

$$
F h=\frac{R^{2} / K}{\left(1-R^{2}\right) / n-K-1}
$$

Sumber: (Sudjana 2002:355)

Tabel 1. Pedoman Interprestasi Koefisien Korelasi

\begin{tabular}{cc}
\hline Interval Koefisien & Tingkat Hubungan \\
\hline $0,000-0,199$ & Sangat Rendah \\
$0,200-0,399$ & Rendah \\
$0,400-0,599$ & Sedang \\
$0,600-0,799$ & Kuat \\
$0,800-1,000$ & Sangat Kuat \\
\hline
\end{tabular}

Sumber: Sugiyono, (2008: 256) 
Keterangan: $\left(\mathrm{R}^{2}\right)=$ Koefisien determinasi $(\mathrm{k})=$ Banyaknya variabel bebas $(\mathrm{n})$ = Banyaknya sampel. Langkah-langkah pengujian: Pertama Menentukan $\mathrm{H}_{0}$ dan $\mathrm{H}_{\mathrm{a}}$

Yaitu Ha $b_{1}{ }^{1} b_{2}{ }^{1} \ldots{ }^{1} b_{3}{ }^{1} 0$, artinya ada pengaruh yang signifikan secara bersama-sama variabel independen terhadap variabel dependen. Level of significance $=$ 0,05

Tahap terakhir dalam uji ini yaitu membuat kesimpulan yaitu dengan membandingkan F hitung dengan F tabel dapat diketahui hubungan antara variabel bebas dan variabel terikat.

Untuk melengkapi alat analisis agar menghasilkan data yang baik dan layak maka digunakan juga alat analisis Uji $\mathrm{t}$ (uji simultan) yaitu pengujian secara parsial digunakan untuk menguji apakah setiap koefisien regresi variabel bebas mempunyai pengaruh atau tidak terhadap variabel terikatnya. Pertama menentukan hipotesis nihil dan hipotesis alternatif

Ho: $\beta=0 \quad$ : Secara individu signifikan variabel bebas tidak berpengaruh terhadap variabel terikat.

Ha: $\beta \neq 0 \quad$ : Secara individu signifikan variabel bebas berpengaruh terhadap variabel terikat. Dengan Level of significance $=0,05$

Menentukan nilai $t_{\text {hitung }}$ yaitu $\mathrm{Uji} t$ digunakan untuk menguji keberartian koefisien regresi secara individu, pengujian terhadap koefisien regresi menurut Rangkuti (2005:165), Uji ini digunakan rumus:

$$
t_{\text {hitung }}=\frac{b}{s b}
$$

Di mana: (b): Koefisien Regresi (sb): Standar Error. Dalamrangka lebih mempermudah dan mempercepat proses analisis ini, maka dipergunakan sistem komputerisasi dengan mempergunakan program dengan program SPSS versi 19.0.

\section{Hasil Penelitian dan Pembahasan}

Hasil pengujian asumsi klasik atas data penelitian pada Sub-Struktur 1 menunjukan hasil sebagai berikut: berdasarkan Uji Asumsi Normalitas Data, dapat dikatakan bahwa data-data dalam penelitian ini merupakan data yang berdistribusi normal. Berdasarkan hasil perhitungan menunjukan total skor mendekati garis normal. Sedang Uji Multikolinieritas menunjukkan nilai tolerance yang lebih besar dari 0.1 atau nilai VIF (Variance Inflation Factor) kurang dari 10. Hal ini berarti bahwa varibel-variabel bebas dalam penelitian tidak terdapat gejala multikolinearitas. Untuk hasil Uji Heteroskedastisitas menunjukan model penelitian ini terbebas dari masalah heterokedastisitas. Dan berdasarkan hasil olah Uji Autokorelasi, ditemukan Durbin Watson test $=2.565$ dan DW berada di atas 2 dapat disimpulkan bahwa data di atas terjadi autokorelasi negatif.

Sedangkan hasil Asumsi Klasik SubStruktur 2 adalah sebagai berikut: Uji Asumsi Normalitas Data menunjukan semua data yang digunakan dalam penelitian ini merupakan data yang berdistribusi normal. Pengujian dengan Uji Multikolinieritas menunjukkan penelitian tidak terdapat gejala multikolinearitas, nilai tolerance yang lebih besar dari 0.1 atau nilai VIF (Variance Inflation Factor) kurang dari 10. Dari hasil Uji Heteroskedastisitas yang dilakukan dapat dilihat bahwa data tidak membentuk suatu pola tertentu. Hal ini berarti model penelitian terbebas dari masalah heterokedastisitas. Dan hasil dari Uji Autokorelasi menunjukan Durbin Watson test $=1.5007$ dan DW berada di antara -2 dan +2 atau - 
$2 \leq \mathrm{DW} \leq+2$ sehingga dikatakan data di atas tidak terjadi autokorelasi.

Uji Analisis Jalur (Path Analysis) Bagian ini menguraikan tiap-tiap jalur dalam model dengan menggunakan analisis jalur, dengan penjabaranmengenaisub-struktur pertama dan sub-struktur yang kedua ditabel 2 .

Pada fungsi 1 (sub-struktur-1), variabel eksogen $=\mathrm{X}_{1}, \mathrm{X}_{2}, \mathrm{X}_{3}$ dan variabel endogen $Y_{1}$ dapat diketahuipersamaan sebagai berikut: $Y_{1}=0.380 X_{1}+0.342 X_{2}-0.477 X_{3}$. Berdasarkan model path yang telah dihasilkan di atas, selanjutnya dapat diinterprestasikan sebagai berikut: (a) Koefisien pengeluaran pemerintah sektor pendidikan $\left(\mathrm{X}_{1}\right)$ sebesar 0.380 , artinya jika variabel eksogen lainnyabernilaitetapdan pengeluaran pemerintah sektor pendidikan $\left(\mathrm{X}_{1}\right)$ mengalami kenaikan 1\%, maka pertumbuhan ekonomi ( $\left.\mathrm{Y}_{1}\right)$ akan mengalami kenaikan sebesar 0.380 . koefisien bernilai positif artinya terjadi hubungan positif antara pengeluaran pemerintah sektor pendidikan terhadap pertumbuhan ekonomi, di mana semakin naik nilai pengeluaran pemerintah sektor pendidikan maka akan semakin meningkat pula pertumbuhan ekonomi. (b) Koefisien pengeluaran pemerintah sektor kesehatan $\left(\mathrm{X}_{2}\right)$ sebesar 0.342, artinya jika variabel eksogen lainnya bernilai tetap dan pengeluaran pemerintah sektor kesehatan $\left(\mathrm{X}_{2}\right)$ mengalami kenaikan $1 \%$, maka pertumbuhan ekonomi $\left(\mathrm{Y}_{1}\right)$ akan mengalami kenaikan sebesar 0.342. koefisien bernilai positif artinya terjadi hubungan positif antara pengeluaran pemerintah sektor kesehatan terhadap pertumbuhan ekonomi, di mana semakin naik nilai pengeluaran pemerintah sektor kesehatan maka akan semakin meningkat pula pertumbuhan ekonomi. (c) Koefisien pengeluaran pemerintah sektor infrastruktur $\left(\mathrm{X}_{3}\right)$ sebesar-0.477, artinya jika variabel eksogen lainnya bernilai tetap dan pengeluaran pemerintah sektor infrastruktur $\left(\mathrm{X}_{3}\right)$ mengalami kenaikan $1 \%$, maka pertumbuhan ekonomi $\left(\mathrm{Y}_{1}\right)$ akan mengalami penurunan sebesar 0.477 . koefisien bernilai negatif artinya terjadi hubungan negatif antara pengeluaran pemerintah sektor infrastruktur terhadap pertumbuhan ekonomi, di mana semakin naik nilai pengeluaran pemerintah sektor infrastruktur maka akan menurunkan pertumbuhan ekonomi.

Pada fungsi 2 (sub-struktur-2), variabel eksogen $=X_{1}, X_{2}, X_{3}, Y_{1}$ dan variabel endogen $\mathrm{Y}_{2}$ dapat diketahui persamaan sebagai berikut: $\mathrm{Y}_{2}=0.422 \mathrm{X}_{1}+0.695 \mathrm{X}_{2}$ $0.346 \mathrm{X}_{3}-0.169 \mathrm{Y}_{1}$. Berdasarkan model path yang telah dihasilkan di atas, selanjutnya dapat diinterprestasikan sebagai berikut: (a) Koefisien pengeluaran pemerintah sektor pendidikan $\left(\mathrm{X}_{1}\right)$ sebesar 0.422 , artinya jika variabel eksogen lainnya bernilai tetap dan

Tabel 2. Nilai koefisien jalur: $\mathrm{X}_{1}, \mathrm{X}_{2}, \mathrm{X}_{3}$, dan $\mathrm{Y}_{1}$

\begin{tabular}{cccccc}
\hline Model & \multicolumn{2}{c}{$\begin{array}{c}\text { Unstandardized Coefficients } \\
\text { B }\end{array}$} & $\begin{array}{c}\text { Standardized } \\
\text { Coefficients } \\
\text { Beta }\end{array}$ & $\mathrm{t}$ & Sig. \\
\hline (Constant) & 1.000 & 2.024 & & .494 & .631 \\
X1 & .154 & .130 & .380 & .1 .185 & .261 \\
X2 & .380 & .378 & .342 & 1.003 & .337 \\
X3 & -.331 & .161 & -.477 & -2.056 & .064 \\
\hline
\end{tabular}

Sumber: Output SPSS. 
Ekonomika-Bisnis Vol. 5 No.1 Bulan Januari Tahun 2014. Hal 1-22

pengeluaran pemerintah sektor pendidikan $\left(\mathrm{X}_{1}\right)$ mengalami kenaikan $1 \%$, maka IPM $\left(\mathrm{Y}_{2}\right)$ akan mengalami kenaikan sebesar 0.422 . koefisien bernilai positif artinya terjadi hubungan positif antara pengeluaran pemerintah sektor pendidikan terhadap IPM, di mana semakin naik nilai pengeluaran pemerintah sektor pendidikan maka akan semakin meningkat pula IPM. (b) Koefisien pengeluaran pemerintah sektor kesehatan $\left(\mathrm{X}_{2}\right)$ sebesar 0.695, artinya jika variabel eksogen lainnya bernilai tetap dan pengeluaran pemerintah sektor kesehatan $\left(\mathrm{X}_{2}\right)$ mengalami kenaikan $1 \%$, maka IPM $\left(\mathrm{Y}_{2}\right)$ akan mengalami kenaikan sebesar 0.695. koefisien bernilai positif artinya terjadi hubungan positif antara pengeluaran pemerintah sektor kesehatan terhadap IPM, di mana semakin naik nilai pengeluaran pemerintah sektor kesehatan maka akan semakin meningkat pula IPM. (c) Koefisien pengeluaran pemerintah sektor infrastruktur $\left(\mathrm{X}_{3}\right)$ sebesar -0.346, artinya jika variabel eksogen lainnya bernilai tetap dan pengeluaran pemerintah sektor infrastruktur $\left(\mathrm{X}_{3}\right)$ mengalami kenaikan $1 \%$, maka IPM $\left(\mathrm{Y}_{2}\right)$ akan mengalami penurunan sebesar -0.346. koefisien bernilai negatif artinya terjadi hubungan negatif antara pengeluaran pemerintah sektor infrastruktur terhadap IPM, di mana semakin naik nilai pengeluaran pemerintah sektor infrastruktur maka akan menurunkan IPM. (d) Koefisien pertumbuhan ekonomi ( $\left.\mathrm{Y}_{1}\right)$ sebesar -0.169, artinya jika variabel pertumbuhan ekonomi $\left(\mathrm{Y}_{1}\right)$ mengalami kenaikan 1\%, maka IPM( $\left.\mathrm{Y}_{2}\right)$ akan mengalami kenaikan sebesar -0.169. koefisien bernilai positif artinya terjadi hubungan positif antara pertumbuhan ekonomi terhadap IPM, di mana semakin naik nilai pertumbuhan ekonomi maka akan semakin meningkat pula IPM.

Untuk mengetahui keeratan hubungan antara variabel independent terhadap dependent dapat dilihat dari nilai koefisien kolerasi (R) serta analisis koefisien determinasi digunakan untuk menunjukkan proporsi variabel dependen yang dijelaskan oleh variabel independen. $\mathrm{R}^{2}$ mampu memberikan informasi mengenai variasi nilai variabel dependen yang dapat dijelaskan oleh model regresi yang digunakan. Apabila $\mathrm{R}^{2}$ mendekati angka satu berarti terdapat hubungan yang kuat. Nilai $\mathrm{R}$ dan $\mathrm{R}^{2}$ yang diperoleh dijelaskan pada tabel4.

Berdasarkan hasil data didapatkan nilai koefisien korelasi sebesar 0,710. Hal ini berarti terdapat hubungan antara pengeluaran pemerintah sektor pendidikan, kesehatan dan infrastruktur terhadap pertumbuhan ekonomi dengan tingkat hubungan kuat karena berada di interval koefisien 0.600 0.799. Sedangkan koefisien determinasi $\left(R^{2}\right)$

Tabel 3. Nilai koefisien jalur: $X_{1}, X_{2}, X_{3}, Y_{1}$ dan $Y_{2}$

\begin{tabular}{|c|c|c|c|c|c|}
\hline \multirow[t]{2}{*}{ Model } & \multicolumn{2}{|c|}{$\begin{array}{l}\text { Unstandardized } \\
\text { Coefficients }\end{array}$} & \multirow{2}{*}{$\begin{array}{c}\text { Standardized } \\
\text { Coefficients } \\
\text { Beta } \\
\end{array}$} & \multirow[t]{2}{*}{$\mathrm{t}$} & \multirow[t]{2}{*}{ Sig. } \\
\hline & $\mathrm{B}$ & Std. Error & & & \\
\hline (Constant) & 36.489 & 8.560 & & 4.263 & .002 \\
\hline X1 & 1.080 & .579 & .422 & 1.866 & .092 \\
\hline X2 & 4.879 & 1.654 & .695 & 2.950 & .015 \\
\hline X3 & -1.517 & .791 & -.346 & -1.917 & .084 \\
\hline Y1 & -1.068 & 1.261 & -.169 & -.847 & .417 \\
\hline
\end{tabular}

Sumber: Output SPSS. 
sebesar 0,504 artinya bahwa $50.40 \%$ variasi dari variabel pertumbuhan ekonomi dapat dijelaskan oleh pengeluaran pemerintah sektor pendidikan, kesehatan dan infrastruktur, sedangkan $49.60 \%$ lainnya dijelaskan oleh variabel lain yang tidak masuk dalam variabel yang diteliti.

Berdasarkan hasil data didapatkan nilai koefisien korelasi sebesar 0,896. Hal ini berarti terdapat hubungan antara pengeluaran pemerintah sektor pendidikan, kesehatan dan infrastruktur serta pertumbuhan ekonomi terhadap IPM dengan tingkat hubungan sangat kuat karena berada di interval koefisien 0.800-1.000. Sedangkan koefisien determinasi $\left(\mathrm{R}^{2}\right)$ sebesar 0,802 artinya bahwa $80,20 \%$ variasi dari variabel IPM dapat dijelaskan oleh pengeluaran pemerintah sektor pendidikan, kesehatan dan infra- struktur serta pertumbuhan ekonomi, sedangkan $29.80 \%$ lainnya dijelaskan oleh variabel lain yang tidak masuk dalam variabel yang diteliti.

Uji F digunakan untuk mengetahui adanya pengaruh variabel eksogen $=\mathrm{X}_{1}, \mathrm{X}_{2}, \mathrm{X}_{3}$ terhadap variabel endogen $\mathrm{Y}_{1}$ dan mengetahui adanya pengaruh variabel eksogen $=$ $\mathrm{X}_{1}, \mathrm{X}_{2}, \mathrm{X}_{3}$ terhadap variabel endogen $\mathrm{Y}_{2}$ serta mengetahui pengaruh variabel eksogen $=\mathrm{X}_{1}, \mathrm{X}_{2}, \mathrm{X}_{3}, \mathrm{Y}_{1}$ terhadap variabel endogen $\mathrm{Y}_{2}$ hasil pengujian secara simultan di tabel 6.

Tabel 6 menunjukkan bahwa secara keseluruhan pada taraf signifikan $(\alpha) 5 \%$ nilai pada tabel ANOVAterlihat nilai signifikansi 0,045 untuk seluruh variabel di mana nilai tersebut lebih kecil dibandingkan dengan taraf signifikan $(\alpha) 5 \%$ (0.05), dengan demikian

Tabel 4. Analisis koefisien korelasi dan koefisien determinasi untuk variabel penelitian $\mathrm{X}_{1}, \mathrm{X}_{2}, \mathrm{X}_{3}$ dan $\mathrm{Y}_{1}$.

\begin{tabular}{ccccc}
\hline Model & $\mathrm{R}$ & R Square & Adjusted R Square & Std. Error of the Estimate \\
1 & $.710^{\mathrm{a}}$ & .504 & .369 & .90621 \\
\hline
\end{tabular}

Sumber: Output SPSS.

Tabel 5. Analisis koefisien korelasi dan koefisien determinasi untuk variabel penelitian $\mathrm{X}_{1}, \mathrm{X}_{2}, \mathrm{X}_{3}, \mathrm{Y}_{1}$ dan $\mathrm{Y}_{2}$.

\begin{tabular}{ccccc}
\hline Model & $\mathrm{R}$ & R Square & Adjusted R Square & $\begin{array}{c}\text { Std. Error of the } \\
\text { Estimate }\end{array}$ \\
\hline 1 & $.896^{\mathrm{a}}$ & .802 & .723 & 3.79148 \\
\hline
\end{tabular}

Sumber: Output SPSS.

Tabel 6. Hasil Analisis Uji F (Uji Simultan) variabel eksogen $=\mathrm{X}_{1}, \mathrm{X}_{2}, \mathrm{X}_{3}$ terhadap variabel endogen $\mathrm{Y}_{1}$.

\begin{tabular}{ccccccc}
\hline \multicolumn{2}{c}{ Model } & $\begin{array}{c}\text { Sum of } \\
\text { Squares }\end{array}$ & Df & $\begin{array}{c}\text { Mean } \\
\text { Square }\end{array}$ & F & Sig. \\
\hline \multirow{2}{*}{1} & Regression & 9.173 & 3 & 3.058 & 3.723 & $.045^{\mathrm{a}}$ \\
& Residual & 9.033 & 11 & .821 & & \\
& Total & 18.206 & 14 & & & \\
\hline
\end{tabular}

Sumber: Lampiran 2, Output SPSS. 
dapat diambil kesimpulan bahwa secara bersama-sama eksogen $=X_{1}, X_{2}, X_{3}$ berpengaruh secara signifikan terhadap variabel endogen $\mathrm{Y}_{1}$.

Tabel 7 menunjukkan bahwa secara keseluruhan pada taraf signifikan $(\alpha) 5 \%$ nilai pada tabel ANOVAterlihat nilai signifikansi 0,002 untuk seluruh variabel di mana nilai tersebut lebih kecil dibandingkan dengan taraf signifikan $(\alpha) 5 \%(0.05)$, dengan demikian dapat diambil kesimpulan bahwa secara bersama-sama variabel eksogen $=\mathrm{X}_{1}, \mathrm{X}_{2}, \mathrm{X}_{3}$, $\mathrm{Y}_{1}$ berpengaruh secara signifikan terhadap variabel endogen $\mathrm{Y}_{2}$.

Uji t (Uji Secara Parsial) ini untuk mengetahui adanya pengaruh variabeleksogen $=X_{1}, X_{2}, X_{3}$ terhadap variabel endogen $Y_{1}$ dan mengetahui adanya pengaruh variabel eksogen $=\mathrm{X}_{1}, \mathrm{X}_{2}, \mathrm{X}_{3}$ terhadap variabel endogen $\mathrm{Y}_{2}$ serta mengetahui pengaruh variabel eksogen $=X_{1}, X_{2}, X_{3}, Y_{1}$ terhadap variabel endogen $\mathrm{Y}_{2}$ hasil pengujian secara parsial di tabel 8 .
Tabel 8 dapat dijelaskan sebagai berikut: Pada level of significant 0.05 , diperoleh nilai signifikansi t sebesar 0.261 di mana nilai tersebut lebih besar dibandingkan dengan level of significant 0.05 , Dengan demikian variabel pengeluaran pemerintah sektor pendidikan $\left(\mathrm{X}_{1}\right)$ terbukti tidak berpengaruh signifikan terhadap variabel pertumbuhan ekonomi $\left(\mathrm{Y}_{1}\right)$. Pada level of significant 0.05 , diperoleh nilai signifikansit sebesar 0.337 di mana nilai tersebut lebih besar dibandingkan dengan levelof significant 0.05 , Dengan demikian variabel pengeluaran pemerintah sektor kesehatan $\left(\mathrm{X}_{2}\right)$ terbukti tidak berpengaruh signifikan terhadap variabel pertumbuhan ekonomi ( $\left.\mathrm{Y}_{1}\right)$. Pada level of significant 0.05 , diperoleh nilai signifikansi $\mathrm{t}$ sebesar 0.064 di mana nilai tersebut lebih besar dibandingkan dengan level of significant 0.05 , Dengan demikian variabel pengeluaran pemerintah sektor infrastuktur $\left(\mathrm{X}_{3}\right)$ terbukti tidak berpengaruh signifikan terhadap variabel pertumbuhan ekonomi $\left(\mathrm{Y}_{1}\right)$.

Tabel 7. Hasil Analisis Uji F (Uji Simultan) variabel eksogen $=\mathrm{X}_{1}, \mathrm{X}_{2}, \mathrm{X}_{3}, \mathrm{Y}_{1}$ terhadap variabel endogen $\mathrm{Y}_{2}$.

\begin{tabular}{ccccccc}
\hline \multirow{2}{*}{ Model } & $\begin{array}{c}\text { Sum of } \\
\text { Squares }\end{array}$ & Df & $\begin{array}{c}\text { Mean } \\
\text { Square }\end{array}$ & F & Sig. \\
\hline \multirow{2}{*}{1} & Regression & 581.992 & 4 & 145.498 & 10.121 & $.002^{\mathrm{a}}$ \\
& Residual & 143.753 & 10 & 14.375 & & \\
& Total & 725.745 & 14 & & & \\
\hline
\end{tabular}

Sumber: Output SPSS.

Tabel 8. Hasil Analisis Uji t (Uji Parsial) variabel eksogen $=\mathrm{X}_{1}, \mathrm{X}_{2}, \mathrm{X}_{3}$ terhadap variabel endogen $\mathrm{Y}_{1}$.

\begin{tabular}{|c|c|c|c|c|c|}
\hline \multirow[t]{2}{*}{ Model } & \multicolumn{2}{|c|}{$\begin{array}{c}\text { Unstandardized } \\
\text { Coefficients }\end{array}$} & \multirow{2}{*}{$\begin{array}{c}\text { Standardized } \\
\text { Coefficients } \\
\text { Beta } \\
\end{array}$} & \multirow[t]{2}{*}{$\mathrm{t}$} & \multirow[t]{2}{*}{ Sig. } \\
\hline & $\mathrm{B}$ & Std. Error & & & \\
\hline (Constant) & 1.000 & 2.024 & & .494 & .631 \\
\hline $\mathrm{X} 1$ & .154 & .130 & .380 & .1 .185 & .261 \\
\hline $\mathrm{X} 2$ & .380 & .378 & .342 & 1.003 & .337 \\
\hline $\mathrm{X} 3$ & -.331 & .161 & -.477 & -2.056 & .064 \\
\hline
\end{tabular}

Sumber: Output SPSS. 
Tabel 9 dapat dijelaskan sebagai berikut: Pada level of significant 0.05 , diperoleh nilai signifikansi t sebesar 0.092 di mana nilai tersebut lebih besar dibandingkan dengan level of significant 0.05 , Dengan demikian variabel pengeluaran pemerintah sektor pendidikan $\left(\mathrm{X}_{1}\right)$ terbukti tidak berpengaruh signifikan terhadap variabel IPM $\left(\mathrm{Y}_{2}\right)$. Pada level of significant 0.05 , diperoleh nilai signifikansit sebesar 0.015 di mana nilai tersebut lebih kecil dibandingkan dengan level of significant 0.05 , Dengan demikian variabel pengeluaran pemerintah sektor kesehatan $\left(\mathrm{X}_{2}\right)$ terbukti berpengaruh signifikan terhadap variabel IPM $\left(\mathrm{Y}_{2}\right)$. Pada level of significant 0.05 , diperoleh nilai signifikansi t sebesar 0.084 di mana nilai tersebut lebih besar dibandingkan dengan level of significant 0.05 , Dengan demikian variabel pengeluaran pemerintah sektor infrastuktur $\left(\mathrm{X}_{3}\right)$ terbukti tidak berpengaruh signifikan terhadap variabel IPM $\left(\mathrm{Y}_{2}\right)$. Pada level of significant 0.05 , diperoleh nilai signifikansi t sebesar 0.417 di mana nilai tersebut lebih besar dibandingkan dengan level of significant 0.05 , Dengan demikian variabel pertumbuhanekonomi $\left(\mathrm{Y}_{1}\right)$ terbukti tidak berpengaruh signifikan terhadap variabel IPM $\left(\mathrm{Y}_{2}\right)$.

Jadi dapat diketahui dari analisis diatas model persamaan analisis regresi untuk dua jalur adalah sebagai berikut; Untuk persama- an substruktur pertama: $\mathrm{Y}_{1}=0.380 \mathrm{X}_{1}+0.342$ $X_{2}-0.477 X_{3}+49,60 \%$, Di mana: $E_{1}=1$ $-\mathrm{R}$ square $=1-0,504=0,496=49,60 \%$. Untuk persamaan substruktur kedua: $\mathrm{Y}_{2}=$ $0.422 \mathrm{X}_{1}+0.695 \mathrm{X}_{2}-0.346 \mathrm{X}_{3}-0,169 \mathrm{Y}_{1}+$ 19,80\%, Di mana: $\mathrm{E}_{2}=1-\mathrm{R}$ square $=1-$ $0,802=0,198=19,80 \%$.

Rangkuman beberapa hasil dari pengujian alat-alat analisis yang telah dijelaskan di atas adalah sebagai berikut. Berdasarkan hasil persamaan substruktur pertama diketahui bahwa setiap perubahan variabel pengeluaran pemerintah sektor pendidikan, kesehatan dan infrastruktur akan memberikan pengaruh terhadap pertumbuhan ekonomi di Provinsi Kalimantan Timur. Dalam persamaan substruktur pertama juga diperoleh informasi bahwa pengeluaran pemerintah sektor pendidikan, kesehatan dan infrastruktur memberikan pengaruh langsung terhadap pertumbuhan ekonomi dengan estimasi angka sebagai berikut: 1) Pengaruh langsung pengeluaran pemerintah sektor pendidikan terhadap pertumbuhan ekonomi sebesar 0,380 atau $38 \%$; 2) Pengaruh langsung pengeluaran pemerintah sektor kesehatan terhadap pertumbuhan ekonomi sebesar 0,342 atau 34,20\%; 3) Pengaruh langsung pengeluaran pemerintah sektor infrastruktur terhadap pertumbuhan ekonomi sebesar $-0,477$ atau $-47,70 \%$.

Tabel 9. Hasil Analisis Uji $F$ (Uji Simultan) variabel eksogen $=X_{1}, X_{2}, X_{3}, Y_{1}$ terhadap variabel endogen $\mathrm{Y}_{2}$.

\begin{tabular}{|c|c|c|c|c|c|}
\hline \multirow[t]{2}{*}{ Model } & \multicolumn{2}{|c|}{$\begin{array}{l}\text { Unstandardized } \\
\text { Coefficients }\end{array}$} & \multirow{2}{*}{$\begin{array}{c}\text { Standardized } \\
\text { Coefficients } \\
\text { Beta } \\
\end{array}$} & \multirow[t]{2}{*}{$\mathrm{t}$} & \multirow[t]{2}{*}{ Sig. } \\
\hline & $\mathrm{B}$ & Std. Error & & & \\
\hline (Constant) & 36.489 & 8.560 & & 4.263 & .002 \\
\hline $\mathrm{X} 1$ & 1.080 & .579 & .422 & 1.866 & .092 \\
\hline $\mathrm{X} 2$ & 4.879 & 1.654 & .695 & 2.950 & .015 \\
\hline X3 & -1.517 & .791 & -.346 & -1.917 & .084 \\
\hline Y1 & -1.068 & 1.261 & -.169 & -.847 & .417 \\
\hline
\end{tabular}

Sumber: Output SPSS. 
Berdasarkan hasil persamaan substruktur kedua diketahui bahwa setiap perubahan variabel pengeluaran pemerintah sektor pendidikan, kesehatan dan infrastruktur serta pertumbuhan ekonomi akan memberikan pengaruh terhadap indeks pembangunan manusia di Provinsi Kalimantan Timur. Dalampersamaan substruktur kedua juga diperoleh informasi bahwa pengeluaran pemerintah sektor pendidikan, kesehatan dan infrastruktur serta pertumbuhan ekonomi memberikan pengaruhlangsung terhadap indeks pembangunan manusia dengan estimasi angka sebagai berikut: 1) Pengaruh langsung pengeluaran pemerintah sektor pendidikan terhadap IPM sebesar 0,422 atau 42,20\%; 2) Pengaruh langsung pengeluaran pemerintah sektor kesehatan terhadap IPM sebesar 0,695 atau 69,50\%; 3) Pengaruh langsung pengeluaran pemerintah sektor infrastruktur terhadap IPM sebesar -0,346 atau $-34,60 \%$; 4) Pengaruh langsung pertumbuhan ekonomi terhadap IPM sebesar -0,169 atau $16,90 \%$.

Berdasarkan persamaan substruktur pertama dan substruktur kedua diperoleh pengaruh tidak langsung variabel pengeluaran pemerintah sektor pendidikan, kesehatan dan infrastruktur terhadap IPM melalui pertumbuhan ekonomi dengan estimasi angka sebagai berikut: 1) pengaruh tidak langsung pengeluaran pemerintah sektor pendidikan terhadap IPM melalui pertumbuhan ekonomi sebesar $0,380 \times(-0,169)=-0,064$ atau sebesar $6,40 \%$;2) pengaruh tidak langsung pengeluaran pemerintah sektor kesehatan terhadap IPM melalui pertumbuhan ekonomi sebesar $0,342 \times(-0,169)=-0,058$ atau sebesar $5.80 \%$; 3 ) pengaruh tidak langsung pengeluaran pemerintah sektor infrastruktur terhadap IPM melalui pertumbuhan ekonomi sebesar $-0,477 \times(-0,169)=0.080$ atau sebesar $8 \%$.
Hasil penelitian menunjukkan bahwa pengeluaran pemerintah sektor pendidikan dan kesehatan memberikan pengaruh positif tetapi tidak signifikan terhadap pertumbuhan ekonomi di Kalimantan Timur, sedangkan pengeluaran pemerintah sektor infrastruktur memberikan pengaruh negatif dan tidak signifikan terhadap pertumbuhan ekonomi di Kalimantan Timur.

Hal ini karena pemerintah memang sangat memprioritaskan sektor pendidikan ini, di mana setiap tahunnya juga pemerintah Indonesia terus berupaya agar amanah konstitusi yaitu anggaran dari APBN untuk pendidikan minimal $20 \%$ dapat terealisasi secara baik. Besarnya perhatian pemerintah terhadap pendidikan bangsa ini juga bisa dilihat dari makin besarnya anggaran yang dikeluarkan pemerintah sampai sekarang ini. Juga dari makin banyaknya realisasi programprogram pendidikan seperti pendidikan gratis untuk Sekolah Dasar dan Sekolah Menengah Pertama, program beasiswa bagi siswa tidak mampu yang juga terus berjalan hingga saat ini, akan tetapi perbaikan anggaran pendidikan ini belum dapat dirasakan langsung untuk perbaikan pertumbuhan ekonomi dalam jangka pendek. Perbaikan pendidikan akan berdampak pada pertumbuhan ekonomi dalam jangka panjang.

Pengeluaran pemerintah sektor kesehatan belum signifikan dikarenakan pengaruh anggaran pemerintah untuk kesehatan terhadap perbaikan ekonomi bahwa ternyata anggaran yang dialokasikan untuk sektor kesehatan tidak selalu tepat diarahkan untuk memperbaiki alokasi kesehatan. Setidaknya ditemukan beberapa penjelasan yakni karena kelemahan kapasitas tenaga perencana dan pelaksana program, maupun terjadinya proses rent seeking yang sangat dahsyat sehingga nilai dari 
proyek tidak sampai pada sasaran program yang sebenarnya.

Pengeluaran pemerintah sektor infrastruktur berpengaruh negatif dan tidak signifikanhal inidikarenakan pengeluaran pemerintah dalam sektor ini membutuhkan biaya yang besar untuk melaksanakan berbagai programnya sehingga belum mampu memberikan dampak secara nyata dalam pertumbuhan ekonomi. Pengeluaran pemerintah sektor infrastuktur mempunyai masa jangka panjang sehingga akan baru dirasakan untuk pertumbuhan ekonomidalamjangka waktu yang cukup panjang.

Hasil penelitian ini didukung oleh teori Dornbusch \& Fisher dalam Manik dan Hidayat (2010: 2) yang menyatakan bahwa pengeluran pemerintahmerupakan cerminan dari kebijakan fiskal yang merupakan salah satu instrumen pemerintah untuk mempengaruhi jalannya perekonomian.

Menurut Manik dan Hidayat (2010:7) salah satu fungsi anggaran pemerintah daerah adalah sebagai alat kebijakan fiskal yang digunakan untuk menstabilkan ekonomi dan mendorong laju pertumbuhan ekonomi. Pengeluaran pemerintah (sektor pendidikan, kesehatan maupun infrastruktur) biasanya mencerminkan kebijakan pemerintah dan umumnya pengeluaran pemerintah terus berkembang seiring dengan meningkatnya aktivitas pemerintah dalam perekonomian.

Menurut Setiawan (2006) implikasi dari pembangunan dalam pendidikan adalah kehidupan manusia akan semakin berkualitas. Dalam kaitannya dengan perekonomian secara umum (nasional) semakin tinggi kualitas hidup suatu bangsa, semakin tinggitingkat pertumbuhan dan kesejahteraan bangsa tersebut. Semakin tinggi kualitas hidup / investasi sumber daya manusia yang kualitas tinggi akan berimplikasi juga terhadap tingkat pertumbuhan ekonomi nasional.
Menurut Setiawan (2006) Kesehatan merupakan kebutuhan mendasar bagi setiap manusia, tanpa kesehatan masyarakat tidak dapat menghasilkan suatu produktivitas bagi negara. Kegiatan ekonomi suatu negara akan berjalan jika ada jaminan kesehatan bagi setiap penduduknya. Terkait dengan teori human capital bahwa modal manusia berperan signifikan, bahkan lebih penting daripada faktor teknologi dalam memacu pertumbuhan ekonomi.

Perekonomian yang terintegrasi membutuhkan pembangunan infrastruktur. Menurut kajian ilmiah yang dilakukan Friawan (2008) menjelaskan setidaknya ada tiga alasan utama mengapa infrastruktur penting dalam sebuah integrasi ekonomi. Pertama, ketersedian infrastruktur yang baik merupakan mesin utama pemacu pertumbuhan ekonomi, misalnya studi The World Bank (2004) menyatakan bahwa tingkat pertumbuhan ekonomi yang rendah dalam beberapa tahun terakhir pasca krisis ekonomi 1998 salah satunya dipengaruhi rendahnya tingkat investasi.

Hasil penelitian menunjukkan bahwa pengeluaran pemerintah sektor pendidikan, kesehatan dan pertumbuhan ekonomi memberikan pengaruh positif terhadap indeks pembangunan manusia (IPM) akan tetapi hanya pengeluaran pemerintah sektor kesehatan yang memberikan pengaruh positif dan signifikan terhadap IPM di Kalimantan Timur, sedangkan pengeluaran pemerintah sektor infrastruktur memberikan pengaruh negatif dan tidak signifikan terhadap pertumbuhan ekonomi di Kalimantan Timur.

Untuk perolehan IPMIndonesia juga memang sejak tahun 1991-2008 lebih dipengaruhi oleh peningkatan pada Education Index yang dilihat dari indikator angka melek huruf dan angka partisipasi pendidikan di SD, SMP dan SMA. Peningkatan Kedua pada 
dua indikator inilah yang memberi sumbangsih terhadap Education Index Indonesia sehingga perlahan-lahan dapat meningkat, dan pada akhirnya mendorong perolehan IPM yang lebih tinggi.

Berdasarkan dari studi-studi lain mengenai faktor pengeluaran pemerintah terhadap input pendidikan untuk memperbaiki IPM juga didapati bahwa anggaran pendidikan berupa pengeluaran alat pembelajaran, bu$\mathrm{ku}$, dan labolatorium yang telah dicatat sebagai kebijakan anggaran ternyata lebih besar manfaatnya untuk meningkatkan mutu pendidikan kita.

Pemerintah telah mengalokasikan anggaran yang cukup banyak untuk sektor kesehatan, sedangkan hingga sekarang ini makin banyak program-program kesehatan seperti jaminan kesehatan masyarakat, program keluarga berencana, subsidi obat generik, sampai pelayanan kesehatan gratis yang sedang diselenggarakan secara terus-menerus dan membutuhkan biaya yang sangat banyak terlebih lagi jumlah penduduk yang besar dan jumlah penduduk miskinjuga bertambah tiap tahunnya yang merupakan sasaran pemerintah untuk pelayanan kesehatan.

Pengeluaran pemerintah sektor infrastuktur tidak berpengaruh signifikan terhadap IPM, hal ini karena dari tahun ke tahun pemerintah lebih fokus dalam membiayai sektor-sektor lain di luar sektor sosial sepertipendidikan dan kesehatan. Anggaran pemerintah justru lebih terfokus ke pos-pos lain seperti sektor pertahanan, ketertiban dan keamanan, serta pinjaman pemerintah yang tidak berpengaruh terhadap pembangunan manusia. Sehingga sebaiknya jika pemerintah ingin meningkatkan kualitas sumber daya manusianya, maka sektor-sektor yang berkaitan dengan pembangunan infrastuktur agar lebih diperhatikan.
Hasil penelitian ini didukung oleh penelitian yang dilakukan oleh Widodo, Waridin \& Maria (2011: 2) yang menyatakan bahwa Pembangunan manusia merupakan salah satu indikator bagi kemajuan suatu negara. Suatu Negara dikatakan maju bukan saja dihitung daripendapatan domestik bruto saja tetapi juga mencakup aspek harapan hidup serta pendidikan masyarakatnya. Hal ini sejalan dengan paradigma pembangunan yang berkembang pada tahun 90 -an yaitu paradigma pembangunan yang berpusat pada manusia (human centered development). Secara konsep, pembangunan manusia adalah upaya yang dilakukanuntuk memperluas peluang penduduk untuk mencapai hidup layak, yang secara umum dapat dilakukan melalui peningkatan kapasitas dasar dan daya beli. Pada tataran praktis peningkatan kapasitas dasar adalah upaya meningkatkan produktivitas penduduk melalui peningkatan pengetahuan dan derajat kesehatan. Dengan demikian sekurangnya ada dua sektor yang perlu diperhatikan oleh pemerintah sehubungan dengan upaya memperluas kesempatan penduduknya untuk mencapai hidup layak yaitu pendidikan dan kesehatan. Dalam hal ini bisa terwujud melalui alokasipengeluaran pemerintah di sektor pendidikan dan kesehatan. Dengan meningkatnya alokasi pengeluaran pemerintah di sektor publik tersebut maka akan meningkatkan pula produktivitas penduduk.

Hasil penelitian juga menunjukkan bahwapertumbuhan ekonomi memberikan pengaruh positif terhadap IPM, hal ini menunjukkan bahwa modal manusia yaitu IPM dalam terminologi ekonomi sering digunakan untuk bidang pendidikan, kesehatan dan berbagai kapasitas manusia lainnya yang ketika bertambah dapat meningkatkan produktivitas. Pendidikan memainkan peran kunci dalam hal kemampuan suatu perekonomian untuk 
mengadopsi teknologi modern dan dalam membangun kapasitasnya bagi pembangunan dan pertumbuhan yang berkelanjutan. Kesuksesan dalam pendidikan bergantung juga pada kecukupankesehatan. Di samping itu kesehatan merupakan prasayarat bagi peningkatan produktivitas. Dengan demikian kesehatan dan pendidikan dapat juga dilihat sebagai komponen vital dalam pertumbuhan dan pembangunan sebagai input bagi fungsi produksi agregat (Todaro, 2002).

Menurut Mill pembangunan ekonomi sangat tergantung pada dua jenis perbaikan, yaitu perbaikan dalam tingkat pengetahuan masyarakat dan perbaikan yang berupa usaha-usaha untuk menghapus penghambat pembangunan sepertiadat istiadat, kepercayaan dan berpikir tradisional. Perbaikan dalam pendidikan, kemajuan dalamilmu pengetahuan, perluasan spesialisasi dan perbaikan dalam organisasi produksi merupakan faktor yang penting yang akan memperbaiki mutu dan efisiensi faktor-faktor produksi dan akhirnya menciptakan pembangunanekonomi. Menurut Mill, faktor pendidikan melaksanakandua fungsi yaitu: mempertinggipengetahuan teknik masyarakat dan mempertinggi ilmu pengetahuan umum. Pendidikan dapat menciptakan pandangan-pandangan dan kebiasaan modern dan besar perannya untuk menentukan kemajuan ekonomi masyarakat.

Menurut Mankiw (2003) modal manusia adalah pengetahuan dan kemampuan yang diperoleh oleh para pekerja melalui pendidikan mulai dari program untuk anak-anak sampai dengan pelatihan dalam pekerjaan (on the job training) untuk para pekerja dewasa. Seperti halnya dengan modal fisik, modal manusia meningkatkan kemampuan untuk memproduksi barang danjasa. Untuk meningkatkan level modal manusia dibutuhkan investasi.
Sementara itu untuk menyesuaikan dengan tingkat pertumbuhan penduduk yang tinggi, negara-negara berkembang harus memperhatikan kualitas sumber daya manusia, dengan mewujudkan program-program spesifik yakni (Samuelson dan Nordhaus, 2001). Mengendalikan penyakit serta meningkatkan kesehatan dan nutrisi. Meningkatkan standar kesehatan penduduk menyebabkan peningkatan produktivitas mereka sebagai tenaga kerja. Pusat kesehatan masyarakat dan penyediaan air bersih merupakan modal sosial yang bermanfaat. 2. Meningkatkan pendidikan, menurunkan angka buta huruf dan melatih tenaga kerja. Manusia terdidik merupakan tenaga kerja yang lebih produktif karena mampu menggunakan modal secara lebih efektif, mampu mengadopsi teknologi dan mampu belajar dari kesalahan. 3. Di atas semua itu, tidak boleh mengestimasi secara lebih rendah (under estimate) terhadap pentingnya sumberdaya manusia.

Becker (1993) mengemukakan bahwa teori modal manusia telah menjadi pemikiran banyak pihak sejalan dengan berhasilnya umat manusia mengendalikan tingkat pertumbuhan penduduk, menanggapikekhawatiran Malthus akan adanya bencana bagi umat manusia bila penduduk terus bertambah. Teori modal manusia pada dasarnya membahas proses merumuskan bentuk-bentuk investasi yang bisa ditanamkan kepada manusia, sebab manusia diakui sebagai salah satu sumber daya yang diperlukan dalam kegiatan produksi barang dan jasa dalam perekonomian.

\section{Penutup}

Substruktur pertama dalam penelitian ini menunjukkan bahwa variabel pengeluaran pemerintah sektor pendidikan, kesehatan dan infrastruktur memberikan pengaruh secara langsung tidak signifikan terhadap per- 
Ekonomika-Bisnis Vol. 5 No.1 Bulan Januari Tahun 2014. Hal 1-22

tumbuhan ekonomi di Kalimantan Timur. Pengeluaran pemerintah sektor pendidikan dan kesehatan memberikan pengaruh positif tetapi tidak signifikan terhadap pertumbuhan ekonomi di Kalimantan Timur, sedangkan pengeluaran pemerintah sektor infrastruktur memberikan pengaruhnegatifdantidak signifikan terhadap pertumbuhan ekonomi di Kalimantan Timur.

Substruktur kedua dalam penelitian ini menunjukkan bahwa variabel pengeluaran pemerintah sektor pendidikan dan kesehatan serta pertumbuhan ekonomi memberikan pengaruh secara langsung dan tidak signifikan terhadap indeks pembangunan manusia (IPM) di Kalimantan Timur. pengeluaran pemerintah sektor pendidikan, kesehatan dan pertumbuhan ekonomi memberikan pengaruh positif terhadap indeks pembangunan manusia (IPM) akan tetapi hanya pengeluaran pemerintah sektor kesehatan yang memberikan pengaruh positif dan signifikan terhadap IPM di Kalimantan Timur, sedangkan pengeluaran pemerintah sektor infrastruktur memberikan pengaruh negatif dan tidak signifikan terhadap pertumbuhan ekonomi dan IPM di Kalimantan Timur.

\section{DAFTAR PUSTAKA}

Algifari. 2000. Analisis Regresi, Teori, Kasus \& Solusi. BPFE UGM. Yogyakarta.

Arsyad, Lincoln. 1999. Ekonomi Pembangunan. STIE YKPN. Yogyakarta.

Akdon \& Riduwan. 2009. Rumus dan Data dalam Analisis Statistika. Alfabeta. Bandung.

Dumairy. 1999. Perekonomian Indonesia. Erlangga. Jakarta.
Firdausy CM. 1998. Dimensi manusia dalam pembangunan berkelanjutan. Lembaga Ilmu Pengetahuan Indonesia. Jakarta.

Friawan, Deni. 2008. Kondisi Pembangunan Infrastruktur di Indonesia. CSIS Vol.37. No.2 Juni 2008. Lembaga Penerbit Fakultas Ekonomi Universitas Indonesia. Jakarta.

Kuncoro, Mudrajad. 2010. Masalah, Kebijakan dan Politik Ekonomika Pembangunan. Erlangga. Jakarta.

Manik, Rikwan \& Hidayat Paidi. 2010. Analisis Kausalitas antara Pengeluaran Pemerintah danPertumbuhanEkonomi Sumatera Utara. Jurnal Keuangan dan Bisnis. Volume 2 No. 1 Maret 2010.

Mankiw, N. Gregory. 2008. Teori Makro Ekonomi (Edisi Keempat). Erlangga. Jakarta.

Mulyaningsih, Yani. 2011. Analisis Pengaruh Pengeluaran Pemerintah di Sektor Pendidikan dak Kesehatan Terhadap Pengentasan Kemiskinan Melalui Peningkatan Pembangunan Manusia di Provinsi Jawa Tengah. Jurnal Dinamika Ekonomi Pembangunan, Juli 2011. Volume 1. Nomor 1.

Mustopadidjaya, AR. 2002. Manajemen Proses Kebijakan Publik, Formulasi,. Implementasi dan Evaluasi Kinerja. LAN. Jakarta.

Samuelson, PA, dan Nordhaus WD. 2004. Ilmu Makroekonomi. Edisi Tujuh Belas, Diterjemahkan oleh Gretta, Theresa Tanoto, Bosco Carvallo, dan Anna Elly. PT. Media GlobalEdukasi. Jakarta. 
Pengaruh Pengeluaran Pemerintah Sektor Pendidikan, Kesehatan... (Heri Suparno)

Silalahi, Ulber. 2009. Metode Penelitian Sosial. Refika Aditama. Bandung.

Soebeno, Agoes. 2005. Analisis Pembangunan Manusia dan Penentuan Prioritas Pembangunan Sosial di Jawa Timur. Sekolah Pascasarjana Institut Pertanian Bogor.

Solow, R. M, 1956. A Contribution To The Theory OfEconomic Growht. Quarterly Journal Of Economics 70 (1), 65-94.

Sugiyono. 2008. Statistik Untuk Penelitian.

CV. Alfabeta. Bandung.

Todaro, Michael P. 2006. Pemabangunan Ekonomi di Dunia Ketiga Edisi 9. Erlangga. Jakarta.

Tri Haryanto. 2006. Kemandirian Daerah: Sebuah Perspektif Dengan Metode Path Analysis. Usahawan No. 03 TH XXXV. Maret 2006.

Widodo, Adi. Waridin \& Maria, Johanna. 2011. Analisis Pengaruh Pengeluaran Pemerintah di Sektor Pendidikan dan Kesehatan Terhadap Pengentasan Kemiskinan Melalui Peningkatan Pembangunan Manusia di Provinsi Jawa Tengah. Jurnal Dinamika Ekonomi Pembangunan, Juli 2011. Volume 1 Nomor 1. 
